\title{
IMPROVE LISTENING ABILITY THROUGH DICTATION TECHNIQUE IN DESCRIPTIVE TEXT AT SMK HKBP PEMATANGSIANTAR
}

\author{
Anita Sitanggang ${ }^{1}$, Anne Silvia Panjaitan ${ }^{2}$, Ita Christine Sinaga ${ }^{3}$, Ruth Junisa A. Siburian ${ }^{4}$ \\ $1,2,3$ \\ University of HKBP Nommensen Pematangsiantar \\ E-mail: ${ }^{1)}$...@gmail.com, ${ }^{2)}$ gmail.com, ${ }^{3)}$ gmail.com
}

\begin{abstract}
This research aims to improve listening ability students of English subjects using the dictation method and find the effectiveness of the dictation method in an effort to improve ability listening to students on descriptive text of class X IA 1 students of SMK HKBP PEMATANGSIANTAR. This research is a classroom action research conducted in the first semester of the year 2021/2022 teaching. The subjects of this research were students of class $X I A I S M K H K B P$ PEMATANGSIANTAR. The object of this research is the improvement of listening ability English lessons on descriptive text with the dictation method. Classroom action research it covers 2 cycles. Each cycle consists of four stages, namely: (1) planning, (2) action, (3) observation, and (4) reflection. The findings from classroom action research are (1) Students' listening ability increase with the use of the dictation method, (2) The average score of students in the pre-cycle action is $56.84 \%$ including the "less" category, the average student score in cycle 1 is $70.47 \%$ including the "enough" category, the average student score in cycle 2 is 78.43\% including the "good" category. (3) Attainment of listening competence skill is measured by the dictation method which shows an increase in the results of research from pre-cycle to cycle II.
\end{abstract}

Keywords: Dictation Method, Listening Ability, Descriptive Text

\section{INTRODUCTION}

Language has an important role in intellectual, social and emotional development people who study. English is good communication tool through conversation or writing. English at the vocational level school has a purpose on the development of communication competence students and students' understanding of relationship between language and culture. A competency that must be conveyed to students includes listening, speaking, reading and writing. Listening or listening ability are the first of all students get.

According to Tarigan (2008), competence consists of four linguistic abilities: (1) listening capacity, (2) speaking ability, (3) reading ability, and (4) writing ability.

Every skill close very related to other ability. In acquiring language ability, starting from learning to listen to the language, then speaking, and then learning to read and write. The four abilities are basically a unified competency that must be mastered by students in language learning.

Competence in this research refers to listening ability for students in monologue texts. Basic competence in listening comprehension is taken from Curriculum (Content Standard), BSNP. BSNP has given consideration to three basic abilities that must be achieved by students. They include students who can understand and respond to interpersonal, transactional conversational texts and respond to short functional texts, as well as understand 
and respond to monologues in long functional texts. To achieve the above competencies required a long learning process and carried out in earnest. After the learning process takes place automatically we have to assess the success of the learning process by measuring students' abilities through tests. It turns out that the ability of students' listening ability in responding to monologue texts of English subjects, especially descriptive texts in class X IA 1 SMK HKBP PEMATANGSIANTAR is relatively low. This can be seen from the research findings data obtained when not using the right method. Listening learning is $56.84 \%$ while the listening competency value that reaches a minimum mastery value is only $9.45 \%$. With such conditions, we must find solutions to improve the quality of learning outcomes and we begin with the ability to understand listening ability and indeed require a serious learning process. With the condition that the achievement results are relatively low, then a solution must be found to improve the ability of ability listening with dictation method. With dictation, some students have difficulty understanding some words that have almost the same pronunciation but have different meanings. They ask the teacher to repeat difficult words that can be trained to students; they have more opportunities for practice/practice, so they are forced to write, read and finally are able to respond to some monologue readings dictated by the teacher or readers on tape.

Based on the identification of the problem above then the limitation of the problem in this research is the ability to improve students' listening ability, the factors that affect the ability to increase students' listening ability includes: internal and external factors. Internal factors from students include the ability of students to improve listening ability while external factors include teacher guidance in improving listening ability in the form of guidance using dictation.

The purpose of this classroom action research can be formulated as follows (1) to describe the improvement of students' listening skills in descriptive texts in class X IA 1 SMK HKBP PEMATANGSIANTAR by using the dictation method. (2) Describe the effectiveness of using the dictation method in improving students' listening skills in descriptive texts for class X IA 1 students of SMK HKBP PEMATANGSIANTAR. This research is intended to provide several advantages or benefits both in theory and practice. Theoretically there are two, namely the use of dictation theory can be used to improve students' ability in listening skills and as a basis of reference for carrying out research with different monologue texts. In practice, it is broken down into students, teachers, schools and the Education Office. For students, there are three, namely increasing student achievement in cognitive, affective, and psychomotor, increasing student creativity in the teaching and learning process using the dictation method and increasing student competence in listening skills. For teachers, there are two types, namely research motivating teachers to increase the use of dictation methods in the teaching and learning process for other types of texts and research motivating teachers to find new methods or other methods in the teaching and learning process. For schools, there are two ways, namely improving the quality of school administration and making a better contribution to improving the learning process. For the Department of Education, there are two, namely providing the basis and arguments for policies to be taken to improve the quality of education and as study material to develop other research and improvement of learning in order to improve the quality of teaching and learning outcomes for the world of education. 


\section{JOURNAL OF HUMANITIES, SOCIAL SCIENCES AND BUSINESS (JHSSB) \\ VOLUME 1 ISSUE 2 (2022)}

\section{THEORETICAL BASIS}

Learning that takes place in today's life is required to provide innovative and creative learning that is also fun so that children are not bored or monotonous but the main material must be conveyed. With the above value situation, the action taken to improve listening learning outcomes is through the method of dictation. From the explanation above, dictation will be applied in the teaching and learning process in the classroom by reading a monologue between 50 to 100 words. Students are asked to listen carefully to be able to receive the message in the reading when the teacher reads the monologue it means the teacher do dictations or language cool dictations. According to the Big Indonesian Dictionary (KBBI) the meaning or understanding of the word dictation and according to linguists and from other sources of information the meaning of the word.

Spoken or read aloud for someone else to write; then we give dictation exercises to learn to write properly. After that, they held a dictation test with the aim of knowing the students' skills in writing the words they had learned to spell. So, dictating means telling people to write what is read or said. In dictation or dictation, taking a listening skill test, a short monologue text between 50 to 100 words is chosen and the pronunciation is repeated 3 times, why this is done because junior high school students if the monologue text is too long students are still very difficult to catch the message content or speech dictated by the teacher. Teachers to do dictation through several stages: First the usual speed; length of word groups, length of pauses, speed of text read and complexity of writing, grammar and vocabulary used in sentences Then dictation is applied by choosing a descriptive monologue text in simple word groups, the speed of the text is read normally and sometimes slowly, the important thing is that students understand the message conveyed in the text. While the complexity of writing is sought that is simple in addition to the selection of grammar and vocabulary that are often used in everyday life. Another element of dictation is judgment. The scoring criteria for several types of possible errors in dictation are as follows; (a) Spelling error, but the word that appears has been heard correctly. (b) Spelled or misrepresented the previous word, unreadable word. (c) Grammatical errors. (d) Words or phrases that jump. (e) Changes in word order. (f) Placement of words with synonyms that suitable.

In implementing dictation for the learning process in the way described above, to improve listening skills. According to Brown (Brown, 2004) listening is a receiving skill which includes several processes of abilities that are not visible but have meanings that are analyzed in depth from hearing because they are transmitted to the ears and brain. Meanwhile, according to H. G. Tarigan \& Tarigan1987) Listening or listening is an event of listening with full understanding, attention, and appreciation, to get information, including ideas or ideas message and understand the meaning of the communication conveyed by the speaker from the pronunciation through spoken language. In this case reminds us that to understand the meaning of the communication conveyed by the speaker, we must listen carefully and attentively.

Listening events always begin with listening to the sound of the language either directly or through recordings. The sound of language that is caught by the ear is defined as its sound. From the explanation above, we can conclude that listening is a process of understanding information starting with the listening device so that we are able to remember, identify, interpret, assess with full concentration in listening skills from hearing to hearing. 
This is often implied as a component of speaking. We cannot speak a language without also listening. Listening is as a major component in learning and teaching languages. It is not simply a process of receiving unified in inaudible symbols. Therefore, it is clear that listening is an interactive process. Listening often also plays a secondary role for his speaking partner. Good speakers are often unwise in judging more highly than good listeners. Listening as a model of appearance should be designed in the assessment.

In this research, an overview of the framework of thinking carried out is provided. To improve listening skills in descriptive texts for class $X$ IA 1 SMK HKBP PEMATANGSIANTAR by applying the dictation method. This research aims to determine the improvement of listening skills through dictation which is read by the teacher in the form of descriptive text. English is spoken as the first language by the majority of the population in many countries, including the United Kingdom, Ireland, USA, Canada, Australia, New Zealand and a number of Caribbean countries and is the official language of nearly 60 sovereign countries. English is the third most widely spoken mother tongue worldwide. (http://en.m wikipedia. org, wiki, English). In addition, English is also used in communicating at an international level in all areas of life in the world, including in the field of education. Because of the importance of the role of English in the international world, the Indonesian government has established English as a compulsory subject for junior high schools, it is also stated in curriculum 13, based on curriculum 13 there are five types of texts that must be conveyed to junior high school students, namely text descriptive text, procedure text, recount text, narrative text and report text. Therefore, the text is taken according to the class, namely descriptive text. Below is a brief explanation of descriptive text. According to Pardiyono (2006), descriptive text is a text or reading that contains information in a visible form from a visible object, quality or quantity. It can be concluded that descriptive text is a text that is used to describe or describe a particular place, person, or thing or about a real object, which can be a person, object or animal in detail or detail, whether its body, quality or quantity.

According to Pardiyono (2006), text descriptive consists of: social function, writing focus, grammatical patterns, and generics structures. (A) social function / social function, to describe the characteristics or condition of the object by using the word characteristic (B) Grammatical patterns there are three grammar in descriptive text, i.e. using sentences with simple present tense or past tense if the object is extinct, using the predicate with the verb be or has/have or the verb linking verbs, for example: look, seem, sound, taste, get, and use adjective to describe quality or object condition. (C) generic structures/ There are two generic structures, namely identification: introduce who, where, or what described or identified something from a special aspect, people, animals, public places, plants and so on to be described, and description: describe the parts, quality and its properties or describe something to be discussed details, parts, habits, quality, and so on. Language Features or language features in descriptive text there are eight, namely introducing the object specifically, using simple present tense; examples come, visit, get, and rarely use past tense only if extinct objects, using noun phrases; example white house, global warning, nice girl, greenhouse , using adjectives; example hot, blue, lazy, beautiful, etc, prepositions; example in, on, at, under, beside, adverbs (adverb); examples quickly, happily, now, lazily, linking verbs liaison; example is, am, are, become, and use the verb have: have, has, had to describe in detail. In carrying out the approach research (research approach) for improve listening 


\section{JOURNAL OF HUMANITIES, SOCIAL SCIENCES AND BUSINESS (JHSSB) \\ VOLUME 1 ISSUE 2 (2022)}

skill in text descriptive for grade X IA 1 students SMK HKBP PEMATANGSIANTAR by applying dictation method which has the aim of know the improvement of listening skill through dictation read by the teacher in the form of descriptive text.

Based on the material in the 13 curriculum and syllabus from BSNP for class material of VII class, this research refers to descriptive text. Approach implementation research with a deep frame of mind in order to improve listening skills in descriptive text through dictation illustrated on Figure 1.

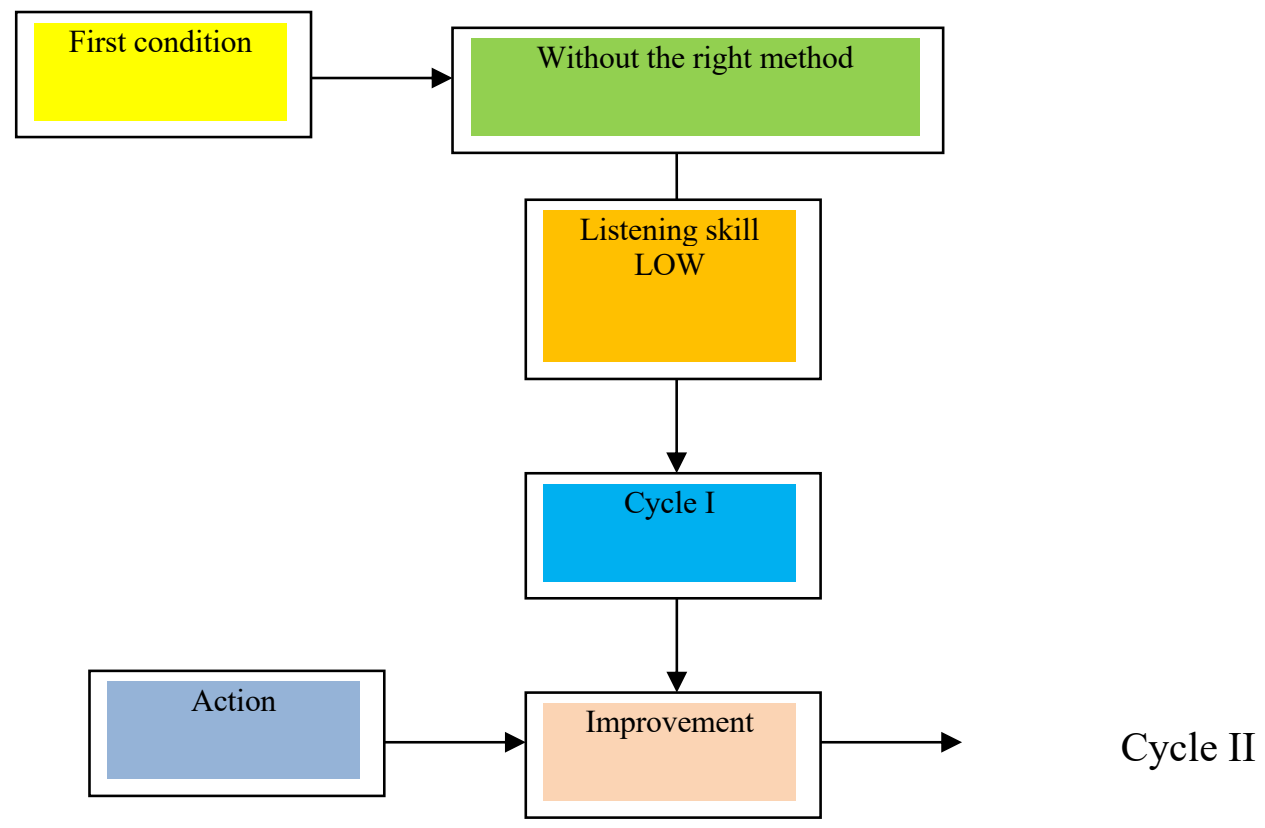

Figure 1 Listening Skills in Descriptive Text

Based on theoretical and framework studies thinking above, the hypothesis is taken: with using teacher dictation can improve students' ability in students' listening skills and descriptive text for class X IA 1 students SMK HKBP PEMATANGSIANTAR.

\section{RESEARCH METHOD}

This research is carried out in Vocational High Schools (SMK) HKBP PEMATANGSIANTAR. This research approach is implemented for four months (from January to February 2022). Research implementation (planning, action, assessment, and reflection), research report writing, and research seminars are all part of the action preparation timetable. The subjects of this research were students at SMK HKBP PEMATANGSIANTAR. Students who become the subjects in this research were class students X IA 1 consists of 32 students. The research approach used is classroom action research according to Mulyadi (2010) classroom action research is an action research conducted in in the classroom when learning takes place, consists of two cycles, to optimize learning methods. Each stage of the cycle includes (1) Planning, (2) Action, (3) Observation, and (4) Reflection. This research approach with reference to research procedures carried out 
through four stages (Wardani, 2014) namely planning, action, observation and reflection. Figure 2 depicts the transparent steps taken.

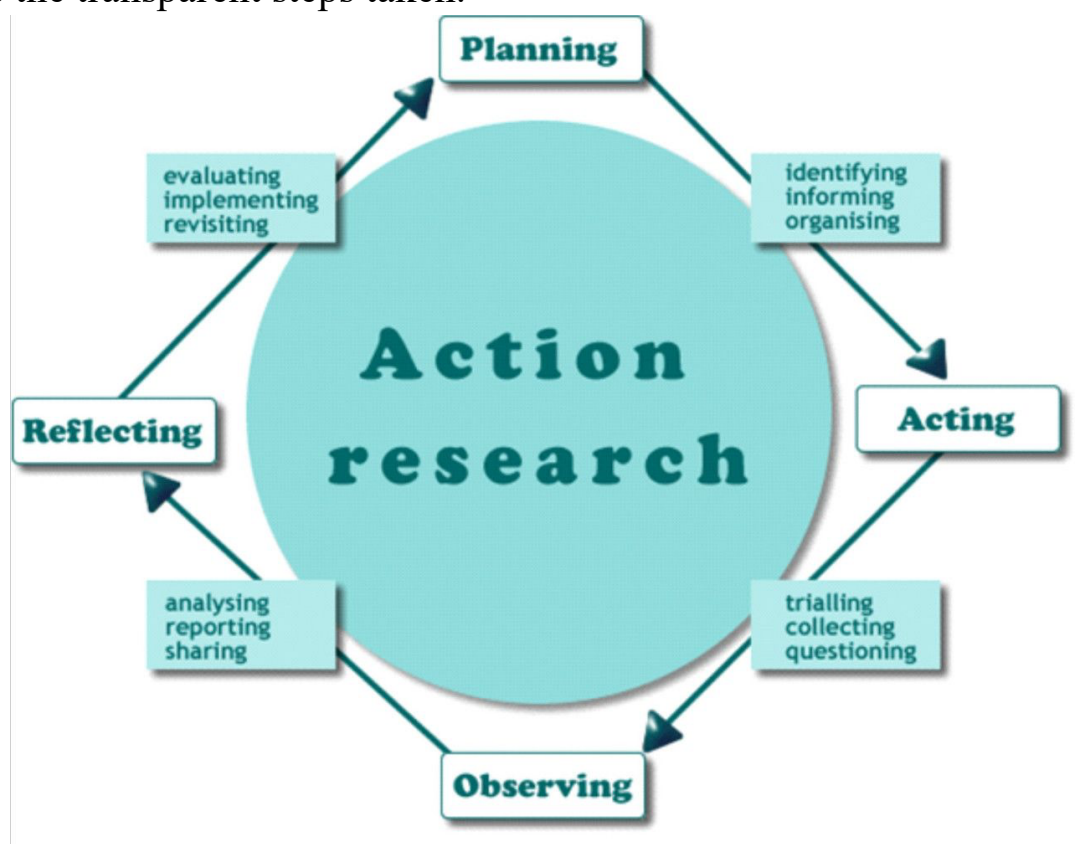

Figure 2 The steps of classroom action research

The object of this research is to improve listening skills in language subjects English in descriptive text type with using the dictation method. There are two types techniques in data collection, namely test and non-test. The test technique is used to know students' competence in listening skills. The non-test technique was used to knowing student responses in listening by using the teacher's dictation. The data used in research approach these are (1) placement and change which refers to the activities of the learning process teach. (2) teacher information providers and student. (3) documents include curriculum, lesson plans, and assessment books. Indicators showing improvement in student achievement in the approach classroom action research can be measured from student achievement in listening skills. This matter shows the average value based on minimum completeness criteria 72 and more than $75 \%$ of the total number of class X IA 1 students reached the minimum completeness score is 72. Quantitative techniques in data analysis taken from dictation which is summed with using (a) Sum the total value of dictation results. (b) Summing up the average achievement/ student achievement in dictation. (c) Sum up percentage. Formula for Percentage of Value, NP: $(\mathrm{NK} \times 100 \%):$ R. NP: Percentage Score, NK: Total Value, R:Number of Respondents

Qualitative techniques are used to analyze qualitative data taken from non-test. The results of the analysis are used to measure the difficulties faced by students in understanding words through dictation. The scoring rubric or criteria used to describe the results of the achievement / achievements in research as follows.(a) Value 86-100 means Very Good, (b) Value 71 - 85 means Good, (c) Value 56 - 70 means Enough, (d) Value 41 - 55 means Less, (d) Value Less than 40 means Very Less.

\section{RESULT AND DISCUSSION}




\section{JOURNAL OF HUMANITIES, SOCIAL SCIENCES AND BUSINESS (JHSSB) \\ VOLUME 1 ISSUE 2 (2022)}

The application of dictation by children really needs a lot of concentration high if you lose concentration then they will miss the read text teachers so that they find it difficult to receive messages next delivered in text the monologue. Dictation learning process as expressed by Mostofa (2013) in imla or dictation skills three basic skills that are developed as for the three things that include accuracy observing, listening and flexibility in write (Norhidayah et al., 2021). In the beginning, imla/dictation aims at develop students' skills in observing words or sentences or text written to be moved or copied into their book. After that, students are trained to move or copy results their hearing. Move practice or copying done by repeatedly brings flexibility student's hand in writing. It becomes capital in skills development write English correctly and well. So Imla 'is very important among the branches of linguistics, it is proof that if we practice copying our hearing results can automatically develop over and over again writing skills (writing skills). Student must be trained as often as possible in order to improve the results of listening competence, children who are full of concentration and want to know how tall they are enthusiastic about following dictation sometimes students ask to repeat one or two words which they find difficult to understand. There are types listening performance as statement Brown (2004) as follows (a) intensive listener. (b) Assessment tasks that we can provide such as, minimal recognition of phonemic pairs, and introduction of paraphrases. (c) Listener responsive. (d) Assessment of tasks that we can give like, correct response to open questions and responses to questions. (e) Selective hearing. (f) Assessment of the tasks that can be assigned such as closed hearing and transfer information. (g) Extensive listenership. (h) Assessment of tasks that we can apply is dictation. (i) Active hearing. (j) Assessment of the tasks we can give such as individual exercise and stimulation. (k) Mutual active listening. (l) Assessment of the tasks that can be given such as discussion, debate, conversation, play roles, partner or group work.

Moreover, some principles of listening assessment comprehension, according to Brown (Brown, 2004) there are two main basic aspects in access listening comprehension like aspects of language and context understanding. Thing it's in the form of micro skills and macro skills: (1) micro skills include nine things (a) distinguish between English sounds special one. (b) Mastering pieces of language of different lengths or in short. (c) Introduce shapes emphasis in English, the word pressed or un pressed position, structure, rhythmic, intonation in its role in information tagging. (d) Introduce reduction of word forms. (e) Distinguish foreign words, introduce core words. (f) Average speaking process on different delivery. (g) Process speaking contains pauses, errors, correction of the delivery variable that other. (h) Introduce groups of words grammatically (noun, verb, and so on) system (tenses, approvals, and plural) rules of pattern and form elliptical. (i) introduce the sentence cohesive in speaking discourse. (2) macro skills/ macro skills include six thing; (a) introduce the communication function in the expression, according to the situation, the actor and destination. (b) Estimating the situation, participants, and purpose of using word knowledge real. (c) Of ideas and others, describe, predict connecting and relationship between events, and effects, and observe relationships as the subject matter, support ideas, new information, giving information. (d) introduce between the meanings of figurative and implicit meaning. (e) using decoration, kinetic, stylistic and non instructions other verbal means to interpret meaning. (f) build and use a series listening strategies such as detecting words key, estimate the meaning of words from the text, request for help, and sign of understanding or lack. After we peel, discuss and analyze the findings in research this, then the results are interpreted in 
accordance with the research objectives, namely interpret competency improvement students' listening skills in descriptive text after using the dictation method and interpret the effectiveness of use dictation method in improving listening skills. It looks that there is an interpretation in stripping, discussion and analysis of the results of the research findings indicate that there is an increase that is from cycle I was found that the average value of listening competence skill increased $70.47 \%$ from the initial cycle only $56.84 \%$ and in cycle II it was also found there is an interpretation of the increase in the findings, namely $78.43 \%$. Stripping, discussion and the analysis doesn't just end there, either found that there is an element of effectiveness the use of dictation we can see that the minimum completeness value experienced improvement in the initial cycle, students who completed only $9.45 \%$ of 32 students, in the cycle I completeness reaches $60.00 \%$, in cycles II completeness reached $80.00 \%$. Hence, based on stripping, discussion and analysis of research findings has interpretation increases.

Based on the results of implementation and observation in the learning process with dictation, the research findings are obtained what is exciting is the dictation that can really improve listening results skills. With the dictation process the teacher can train children's hearing to be more sensitive to English pronunciation or speech get used to it. Students have the opportunity develop listening skills maximum and they get hands-on experience that can they remember for a long time. Implementation of learning process activities dictation cannot be separated from the form of participant interaction learn with the teacher as a facilitator. They need teacher guidance in understanding the appropriate speech / speech with the meaning they mean so the teacher must patiently repeat the pronunciation is finally the students able to write correctly. Therefore, students must follow the steps good dictation. Students attentively follow dictation learning stages that train students to listen to foreign words so they try to find the meaning. They can also write the dictated words so that listening skills improve and also improve writing skills. The stages of the dictation process will be successful if done with care like expressed by Brown (Buck, 2001) Dictation seems to provide a method valid for associating skills listening and writing and tapping in cohesive elements in a language that implied to a short reading. Practice by administration in dictation as follows (a) level of trustworthiness in the system good value creation, (b) relationship strong to other language skills, and (c) broad interpretation in listening comprehensions. Research findings in this cycle are a form of student writing that is dictated by the teacher and non-test consists of observations, and documents. Dictation activity in progress learning has gone through four phases, namely: (1) provide feedback to students by giving oral pressure that has completed their task. (2) Provide confirmation to the results students through other book sources. (3) Facilitate students to reflect their learning experience. (4) motivate students who lack mastery of vocabulary related to monologue "Descriptive" text. From the research, it can be described as the first three things there are some improvements research findings in listening skills in each cycle, the average initial cycle student achievement $56.84 \%$. There is an increase $15.63 \%$ from the initial cycle to the first cycle. Increased student achievement from cycle I to cycle II is $6.87 \%$, both achievements students' listening skills can be measured through teacher dictation. It shows from the description the average value of students who completed from the initial cycle to the first cycle to the second cycle in each cycle has improved both from the results observation findings in the student dictation process or learning outcomes in improving students' listening skills through teacher 


\section{JOURNAL OF HUMANITIES, SOCIAL SCIENCES AND BUSINESS (JHSSB) \\ VOLUME 1 ISSUE 2 (2022)}

dictation. Therefore, it supports the research hypothesis that done, the results are visible in the cycle initial $9.45 \%$ increased to cycle I to by $60.00 \%$ and increasing again to the second cycle to $80.00 \%$, and the third the use of the dictation method used by the teacher can improve the ability students in listening skills, especially text monologue "Descriptive" an important role in practicing listening skills because it is a direct contribution to improve skills or abilities 21 st century, including skills communication, which in this case we train verbal communication and they can put in writing. About the form of writing and the truth in writing can be trained continuously, well in classroom learning or activities outside of the classroom. Related Vocabulary with descriptive monologue text already delivered when students discuss examples of descriptive text in progress classroom learning.

\section{CONCLUSION}

Based on the results of research findings this conclusion can be drawn as follows:

(1) The use of the dictation method is able improve students' listening skills in "Descriptive" text for class X IA 1 semester students SMK HKBP PEMATANGSIANTAR Academic Year 2021/2022. From the average value of listening skill by using dictation $56.84 \%$ in the cycle the initial increase in the first cycle to $70.47 \%$ then increased again towards cycle II to be $78.43 \%$. (2) Usage effective dictation method improves results learns students' listening skills in text "descriptive" class X students. From condition the beginning of the average value of the learning outcomes that have been appreciated on listening competence skills with $9.45 \%$ completeness increase to $60.00 \%$ and increased to condition at the end of the second cycle the average value of learning outcomes which reached a completeness of $80.00 \%$. Based on the findings of this research, there are three things to consider are for teachers, for students, and for English teachers. For teachers it is useful to take advantage of this learning model as an alternative to improve student achievement, the need for other learning that can improve student learning abilities, and with an increase in ability students' listening skills in language lessons English using the dictation method, then asked another teacher to give description of the implementation of language learning English through teacher motivation and as an inspiration to hold classroom action research by applying the use of learning models by teachers in other subjects. (2) For Students, by learning the application of the dictation method students should be able to use it well so that listening skills student skills can increase, and in using the dictation method, students should more active alone and trying to find concepts obtained. Recommended suggestions based on the findings of this research are (1) if students have difficulties in understand dictation tasks easily manipulated by group length words, pause length, fast text speed readability and complexity of writing, grammar and vocabulary used in sentences then we have to help with gesture/ cue. (2) English teacher proposed to use the cooperative method to improve students' language skills. (3) Assessment, assessment criteria for some types of possible errors in dictation as follows; (a) error spell, but the word that appears has been heard properly. (b) Spell or miss represent the previous word, the unread word. (c) Grammatical errors. (d) Word or phrases that jump. (e) Change word order. (f) Placement of words with suitable synonym, therefore teachers must avoid errors in judgment and carefully trying not to make errors to the detriment of students. (4) The teacher uses this model in improve student achievement. (5) With improved communication students in English lessons, then for other teachers can give an idea implementation of English learning through the provision of motivation by the 
teacher and as an inspiration (6) students should more active on their own and trying to apply knowledge gained with more listening skills practice. (7) Assistance and communication between students and teachers at the time of delivery of learning materials especially descriptive text should be done intensively so that students really understand the purpose of descriptive text, structure the text and the characteristics of the descriptive text in detail with the expectations of participants teach if you find the type of descriptive text. In any book you can tell the difference with other types of text. (8) For the Department of Education is expected to provide basis and argument for policy that will be taken for quality improvement education and as study material for develop other research and improvement of learning to improve the quality of the results of the teaching and learning process for education World.

\section{REFERENCES}

Brown, H. D. (2004). Language Assessment Principles and Classroom Practices. Pearson Education Inc.

Buck, G. (2001). 2001: Assessing listening. Cambridge: Cambridge University Press.

Mulyadi. (2010). Membuat Judul Dalam Penelitian Tindakan Kelas/Sekolah. Kementerian Pendidikan Nasional Ditjen Peningkatan Mutu Pendidikan Dan Tenaga Kependidikan Lembaga Penjaminan Mutu Pendidikan Jawa Tengah.

Norhidayah, N., Ilmiani, A. M., \& Marsiah, M. (2021). Implementation of Imla Online Learning. An Nabighoh, 23(2), 183-194.

Pardiyono. (2006). Writing Clues for Better Writing Competence. Andi.

Tarigan, G. (2008). Menulis Sebagai sesuatu keterampilan Keterampilan Bahasa. Bandung: Angkasa.

Tarigan, H. G., \& Tarigan, J. (1987). Teknik pengajaran keterampilan berbahasa. Angkasa, Bandung.

Wardani, I. G. A. K. (2014). Penelitian Tindakan Kelas. Universitas Terbuka. 